\section{Islamic Banking and Finance Review}

\section{=lBFF}

\section{The Determinants of the Pakistan Islamic Banking Industry Profitability: Panel Evidence}

Farrukh Ijaz

Officer Academics, Institute of Islamic Banking University of Management and Technology Lahore, Technology Lahore, Pakistan.

Pakistan.farrukh.ijaz@umt.edu.pk

Syeda Hameeda Batool Gillani

Research Assistant, Institute of Islamic Banking University of Management and Technology Lahore, Pakistan.

\section{Research Paper Information:}

\section{Jo cite this article}

Ijaz, F., Akmal, A., \& Gillani, S. H. B. (2015). The Determinants of the Pakistan Islamic Banking Industry Profitability: Panel Evidence. Islamic Banking and Finance Review, 2 (1), 77-91.

\section{$\underline{\text { Crossref }}$}

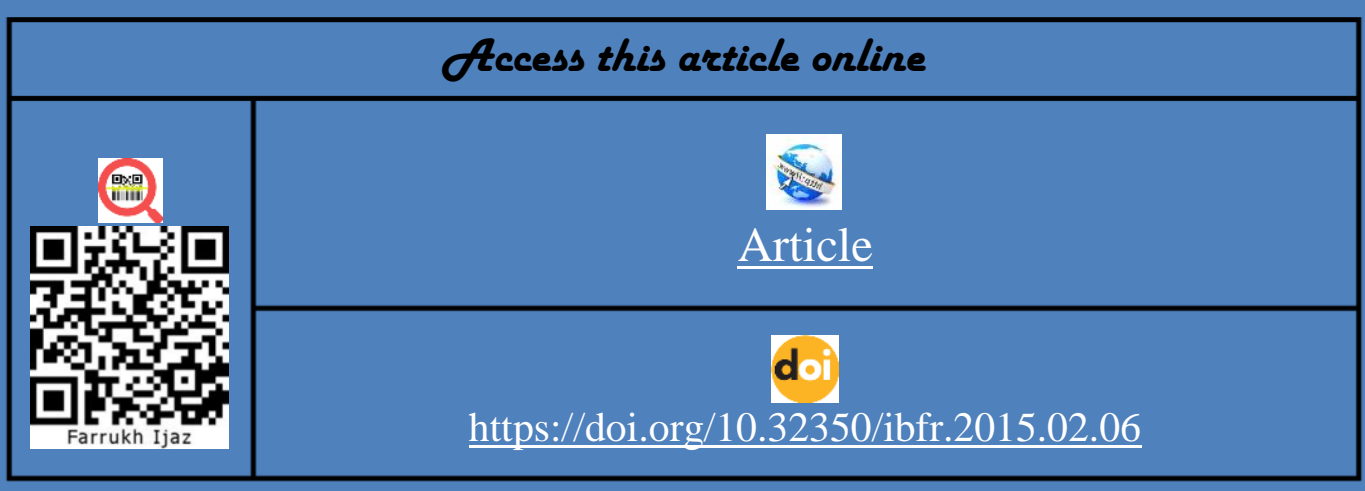

Contact Information
Volume 2

ISSN (E):

ISSN (P):

1436-H/ 2015

2413-2977

2221-5239

\section{Journal doi)}

https://doi.org/10.32350/ibfr

$$
\text { Issue do }
$$

https://doi.org/10.32350/ibfr.2015.02

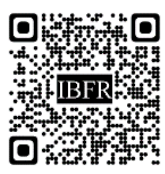

๖

This is an Open Access Journal

\section{Published By}

Institute of Islamic Banking

University of Management and Technology (UMT)

\section{3}

https://iib.umt.edu.pk/ibfr/home.aspx

@

ibfr@umt.edu.pk

This article is distributed under the terms of Creative Commons Attribution - Share Alike 4.0 International License.

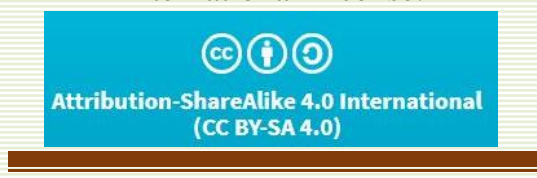

Indexing Partners

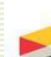

Crossref

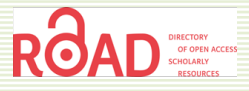

Rit

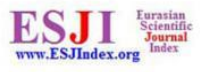

गारे DRJI

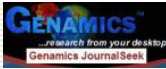

INDEX COPERNICUS DS

INSTITUTE OF ISLAMIC BANKING (IIB) UNIVERSITY OF MANAGEMENT AND TECHNOLOGY 


\title{
The Determinants of the Pakistan Islamic Banking Industry Profitability: Panel Evidence
}

\author{
Farrukh liaz \\ Officer Academics, Institute of Islamic Banking \\ University of Management and Technology \\ Lahore, Pakistan. \\ farrukh.ijaz@umt.edu.pk \\ Anum Akmal \\ Research Assistant, ORIC \\ University of Management and Technology \\ Lahore, Pakistan. \\ Syeda Hameeda Batool Gillani \\ Research Assistant, Institute of Islamic Banking \\ University of Management and Technology \\ Lahore, Pakistan.
}

\begin{abstract}
$\mathrm{T}$

he financial sector plays an important role in the economic and fiscal development of a country. A well-built and vigorous banking system is a precondition for the sustainable financial growth of a country. Over the past few years, Islamic banking industry of Pakistan has been facing many problems and challenges to maintain the financial stability. To overcome this issue, it is vital to classify the factors that mostly impact the overall profitability of Islamic banks in Pakistan. Two models were used alternatively for $\mathrm{ROA}$ and $\mathrm{ROE}$ as dependent variable. A set of internal factors were considered as independent variables including: bank's size, gearing ratio, operational efficiency, asset management and capital adequacy ratio for the time period 2006-2013. The results indicate that different measures of profitability depend upon different bank specific factors. The study found that profitability of Islamic banks depends on the leverage ratio, operating efficiency, asset management and bank size. Further research can be extended to explore the above findings and to include some other internal factors such as general bank charges, doubtful loans or reserves ratios, and external factor such as GDP, exchange rate and CPI as well.
\end{abstract}

Keywords: Islamic Banks, Profitability, ROA, ROE, Bank Size, CAR ljaz, Farrukh., Akmal, Anum., \& Gillani, Syeda Hameeda. Batool. (2015). The Determinants of the Pakistan Islamic Banking Industry Profitability: Panel Evidence. Islamic Banking and Finance Review, 2(1), 77-91. ISSN 2221-5239. (C) 2015 


\section{Introduction}

The financial sector of a country plays an important role in its economic and fiscal development. An economy can't be stabilizing until it has moneymaking financial system. The financial sector in Pakistan consists of Development Financial Institutions (DFI's), Commercial Banks (both Conventional and Islamic Banks), Specialized Banks, Microfinance Banks, Investment Banks, Non-banking Finance Companies (NBFC's), House Finance Companies, Leasing Companies, Mutual Funds and Modarabas. The Pakistan financial sector is well dominated by the presence of domestic and foreign commercial banks. The State Bank of Pakistan (SBP) is responsible for supervisory of these Banks and DFI's, whereas all other financial institutions are being monitored and regulated by the Securities and Exchange Commission of Pakistan (State Bank of Pakistan [SBP], 2007).

After 1997, the privatization of public commercial banks, ongoing process of mergers and introduction of Shariah based banking system bring noteworthy transformation to the financial banking system of Pakistan. The prologue of Islamic banking is an evolving field in global economic market and its development also been praise worthy during the last decade. According to one of the published report of SBP, the Islamic banks growth rate in terms of size and structure is $27 \%$ per annum (SBP, 2013). Islamic banks not only have the flexibility of providing investment banking services and also have the advantage of becoming creditors of firms. Therefore, a broad assessment of the profitability of Islamic banks is essential for managerial as well as regulatory perspectives.

Profitability measurement is a significant technique to determine the growth, vision and future prospects of organizations, firms and sectors. This gives investors, stakeholders and lenders an accurate picture of that particular sector over a period of time. The term "profitability" primarily indicates performance and operational outcomes that reflects overall financial health of the sector over a specific period of time. Although a complete assessment of Islamic banking system profitability take into account many other different kind of measures but most common performance measurement used in the field of finance is financial ratios. 
Therefore, the primary purpose of this study is to address the following research question: "Do bank's internal factors impact the profitability of Islamic banks of Pakistan?"

\subsection{Research Objective}

- To determine whether bank's internal factors impact the profitability of Pakistani Islamic banks.

- To examine the relationship between Return on Assets and bank's internal factors.

- To examine the relationship between Return on Equity and bank's internal factors.

\subsection{Significance of the Study}

Our study differs in two main aspects from the earlier researches. First, the study takes in to account only those factors that have major impact on the banking sector profitability. Secondly, all five full fledge functional Islamic banks, excluding currently operational conventional banks Islamic windows, considers for this study, hence, providing more appropriate and recent empirical evidence to investigate the impact of internal factors determining Pakistani Islamic banks profitability.

\section{Literature Review}

Islamic banks are performing several services and are functional in almost all regions of the world. However, given that the Pakistan is a Muslim country, the Pakistan Islamic banks' market share is still relatively small. Today after ten years, there are only 5 certified Islamic banks are operating in the Pakistan. The network of branches of both conventional banks Islamic window operations and Islamic banks comprise of more than 1,110 branches in over 52 cities of the Pakistan and AJK (SBP, 2013). The concept of Shariah compliance banking not just get acceptance in the Muslims but it also gets flourished in the non-Muslim nations.

This dynamic development of Islamic banking has created significant attention in the financial world. In past, many studies had been conducted to 
determine the factors influencing the profitability of banking sector. Few researchers considered only the bank's internal variables that are in control of management (Bourke, 1989; Williams et al., 1994; Pang, 1995), whereas others included the external environmental factors in their studies (Short, 1979; Bourke, 1989; Molyneux and Thornton, 1992). However, most studies were done on the banking system of the developed economies, and very few studies examining emerging economies such as Pakistan.

Kim and Kim (1997) measured Korean and US commercial banks profitability and found US banks perform well in terms of profitability and efficiency compared to Korean banks. They take deposit ratio, fixed assets ratio, equity ratio and reserves for loans to total assets as independent variable and examine their impact on the ROA and ROE. They found all these variables have positive significant impact on both dependent variables. A similar study was done by Ahmed and Khababa (1999) to measure the profitability of commercial banks by considering four independent variables business risk, market concentration, market size the size of the bank. The study concluded that only bank size and market business risk plays a significant role in the bank's better profitability and performance.

Naceur and Goaied (2001) studied relationship of Tunisian banks profitability and performance with banks capitalization, capital productivity, labor productivity and portfolio composition for the period 1986-1999. They found all of them as significant positive determinants of Tunisian banks performance. Abreu and Mendes (2002) had done a study on four EU countries to determine the profitability of banks with internal and external bank specific characteristics. Chirwa (2003) investigated the Malawi commercial banks profitability using data from 1970-1994. He concluded a significant positive association between market concentration and bank's profitability.

Hassan et al. (2003) measured determinants of profitability through the ROA and ROE of 14 Islamic banks of 8 different countries for the period 19931998 and found loan ratios and capital have significant impact on the profitability indicators. Goddard et al. (2004) found that bank's size has had a positive impact on the banking sector performance of five European countries over the 1990s. Al-Tamimi (2005) found that bank portfolio and 
bank size have highly significant relation with ROA and ROE for the National bank's performance.

Athanasoglou et al. (2006) suggested that all bank specific variables have significant affect on bank's profitability. Wum et al. (2007) studied the impact of financial development, bank age, bank's size, non-interest income ratio, capitalization level, size and GDP per capita on the Chinese commercial banks. Jham and Khan (2008) found that banks profitability directly proportionate to the customer's satisfaction level. Siddiqui (2008) compared two fully Islamic licensed banks of Pakistan with scheduled banks. He found that Islamic banks in Pakistan more inclined in the direction of employing projects with long-term financing and found to have enhanced profitability.

Kosmidou et al. (2008) determines the Greek banks performance from 19902002 using ROA as dependent variable and found positive influence of size and GDP on bank's profitability. Flamini et al. (2009) in their study of 389 banks as sample from 41 Sub-Saharan African countries found credit risk and banks ROA are associated with larger bank size. According to Rajesh \& Sakshi (2009), profitability of banks in India impact greatly by the advance deposits, assets and macroeconomic indicators. Similarly, Deger and Adem (2011) studied the impact of bank specific variables of 10 listed commercial banks on the profitability from 2002-2010 in Istanbul stock exchange and found positive impact of asset's size and non-interest income on the profitability.

Samina (2013) investigate the impact of the bank specific variables and macroeconomic indicators on the profitability of 32 commercial banks during the period of 2006- 2010. She found that there is a significant impact of asset size, leverage ratio, credit risk and interest rate on ROE and ROA. Almazari (2014) investigated the internal factors that affecting profitability of Saudi banks for the period 2005-2011, and found significant positive correlation between ROA and TEA, TIA, LQR variables. Ostadi and Monsef (2014) in their study determine the factors affecting the profitability of commercial banks in Iran. Dependent variable was indicators of profitability, that is, ROE and ROA, and bank deposits, bank size, bank capital, focus on liquidity and banking requirements were independent variables. The results indicate that the effect of bank size and bank concentration on profitability is positive. 


\section{Research Methodology}

The panel data set covers an 8-year period from 2006 to 2013; with a sample size of 5 full fledge Islamic banks of Pakistan. The five selected banks constitute the major and most prominent part in Shariah compliance financing during the period under review (Samina, 2013). The sample data was collected from the secondary sources includes annual reports of the respective Islamic banks.

\subsection{Research Hypothesis}

Based on the objectives, following research hypothesis is formulated.

- $\mathrm{H}_{1}$ : There is a direct relationship between Islamic bank's profitability and bank internal factors.

- $\mathrm{H}_{1 \mathrm{a}}$ : There is a positive significant relationship between Islamic bank's profitability and bank's size.

- $\mathrm{H}_{1 \mathrm{~b}}$ : There is a positive significant relationship between Islamic bank's profitability and gearing ratio.

- $\mathrm{H}_{1 \mathrm{c}}$ : There is a positive significant relationship between Islamic bank's profitability and asset management.

- $\mathrm{H}_{1 \mathrm{~d}}$ : There is a positive significant relationship between Islamic bank's profitability and operational efficiency.

- $\mathrm{H}_{1 \mathrm{e}}$ : There is a positive significant direct relationship between Islamic bank's profitability and capital adequacy ratio.

\subsection{Research Model}

The research model formulated for the study is,

Where

$$
\mathrm{Y}_{\mathrm{i}, \mathrm{t}}=\alpha+\mathrm{X} 1_{\mathrm{i}, \mathrm{\beta}} \beta_{1}+\mathrm{X} 2_{\mathrm{i}, \mathrm{t}} \beta_{2}+\mathrm{X} 3_{\mathrm{i}, \mathrm{t}} \beta_{3}+\mathrm{X} 4_{\mathrm{i}, \mathrm{t}} \beta_{4}+\mathrm{X} 5_{\mathrm{i}, \mathrm{t}} \beta_{5}+€_{\mathrm{i}, \mathrm{t}}
$$

$\mathrm{Y}_{\mathrm{i}, \mathrm{t}}$ represents ROA and ROE for bank $\mathrm{i}$ at time $\mathrm{t}$

$\mathrm{X} 1_{i, t}$ represents natural logarithm of total asset for bank $\mathrm{i}$ at time $\mathrm{t}$

$\mathrm{X} 2_{\mathrm{i}, \mathrm{t}}$ represents gearing ratio for bank $\mathrm{i}$ at time $\mathrm{t}$

$\mathrm{X} 3_{\mathrm{i}, \mathrm{t}}$ represents asset management for bank $\mathrm{i}$ at time $\mathrm{t}$

$\mathrm{X} 4_{\mathrm{i}, \mathrm{t}}$ represents operational efficiency for bank $\mathrm{i}$ at time $\mathrm{t}$ 
$\mathrm{X} 5_{\mathrm{i}, \mathrm{t}}$ represents capital adequacy ratio for bank $\mathrm{i}$ at time $\mathrm{t}$

i represents 1 to 5 banks

$\mathrm{t}$ represents time period from 2006-2013

$€_{\mathrm{i}, \mathrm{t}}$ represents error term

\subsection{Research Variables}

There are three widely known measures of bank profitability: Return on Assets (ROA), Earnings per Share (EPS) and Return on Equity (ROE). There are divergent views among scholars on the superiority of one indicator over the other as a good measure of bank's profitability. According to Naceur \& Goaied (2001), anyone or a combination of the indicators can be used to measure profitability in banks depending on the objective of the user or analyst. ROA and ROE are the largely pertained ratios used to measure financial performance (Naceur \& Goaied, 2001; Kosmidou, 2008; Sufian \& Habibullah, 2009). Table 1 show the variables used in this study.

\section{Table 01: Research Variables}

\begin{tabular}{lcl}
\hline \multicolumn{1}{c}{ Variables } & Symbol & \multicolumn{1}{c}{ Proxies } \\
\hline Return on Asset $\left(\mathrm{Y}_{1}\right)$ & ROA & Annual net income / Average total assets \\
Return on Equity $\left(\mathrm{Y}_{2}\right)$ & ROE & Annual net income / Average total equity \\
Banks Size $\left(\mathrm{X}_{1}\right)$ & SIZE & Log of total assets \\
Gearing Ratio $\left(\mathrm{X}_{2}\right)$ & GR & Total liabilities / Total equity \\
Asset Management $\left(\mathrm{X}_{3}\right)$ & AM & Operating income / Total assets \\
Operational Efficiency $\left(\mathrm{X}_{4}\right)$ & OE & Operating expenses / Total assets \\
Capital Adequacy $\left(\mathrm{X}_{5}\right)$ & CAR & Tier I + Tier II capital / Risk weighted \\
& & assets \\
\hline
\end{tabular}

\subsection{Research Framework}

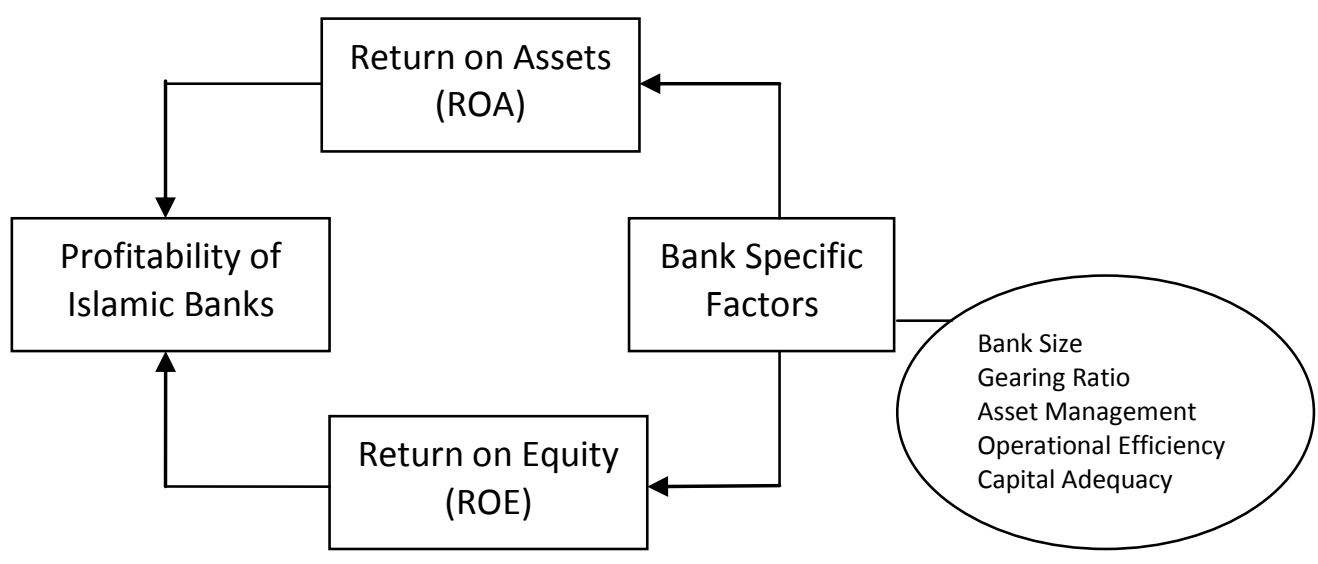




\section{Data Analysis and Results}

\subsection{Descriptive Statistics}

The Table 2 explains the descriptive statistics of all the dependent and independent variables. The value of mean in column two depicts the average of the given variables taken for the study. The volatility in the data set is measured through the standard deviation. The standard deviation value shows the volatility in the data. A small standard deviation point towards that the data points are inclined to be extremely close to the mean. Skewness and Kurtosis values show the deviation in the variables value. The significance level used for this study is 0.05 .

\begin{tabular}{l|ccccc}
\hline \multicolumn{7}{c}{ Table 02: Descriptive Statistics } \\
\hline & Mean & $\begin{array}{c}\text { Standard } \\
\text { Error }\end{array}$ & $\begin{array}{c}\text { Standard } \\
\text { Deviation }\end{array}$ & Kurtosis & Skewness \\
\hline ROA & 0.26 & 0.11 & 0.68 & 2.31 & 0.39 \\
ROE & 4.23 & 1.31 & 8.31 & 1.61 & 1.50 \\
Bank Size & 7.56 & 0.08 & 0.48 & $(0.21)$ & $(0.28)$ \\
Gearing Ratio & 7.42 & 0.77 & 4.84 & $(1.09)$ & 0.31 \\
Asset Management & $(0.00)$ & 0.00 & 0.02 & $(0.06)$ & $(0.83)$ \\
Operating Efficiency & 0.02 & 0.00 & 0.01 & 9.68 & 2.05 \\
Capital Adequacy & 0.25 & 0.02 & 0.15 & $(0.23)$ & 1.04 \\
\hline
\end{tabular}

Table 3 shows the pearson correlation test of all the independent variables used in the study. The test indicates the absence of multi-collinearity problem among all the factors, which means that all the factors taken in to study have no interdependency on each other and free from the issue of correlation of explanatory variables.

\begin{tabular}{l|ccccc}
\hline \multicolumn{7}{c}{ Table 03: Correlation Matrix } \\
\hline & $\mathbf{X}_{\mathbf{1}}$ & $\mathbf{X}_{\mathbf{2}}$ & $\mathbf{X}_{\mathbf{3}}$ & $\mathbf{X}_{\mathbf{4}}$ & $\mathbf{X}_{\mathbf{5}}$ \\
\hline Bank Size & 1.00 & & & & \\
Gearing Ratio & 0.54 & 1.00 & & & \\
Asset Management & 0.43 & 0.40 & 1.00 & & \\
Operating Efficiency & $(0.43)$ & $(0.47)$ & $(0.43)$ & 1.00 & \\
Capital Adequacy & $(0.33)$ & $(0.37)$ & $(0.33)$ & 0.21 & 1.00 \\
\hline
\end{tabular}




\subsection{Panel Data Analysis}

Table 5 and Table 6 represent the results of panel data analysis of the both models. The total number of observations in the each model is 40 . The value of beta for each variable represents the positive or negative impact on the respective dependent variables, if variable is increased by 1 percent. Similarly, $\mathrm{t}$-stat and $\mathrm{p}$-value indicates whether the variables have a significant impact on the ROA and ROE. The R square value specifies the overall strength of the model. The F-statistics value indicates the significance of each model overall, whereas the Durbin-Watson test shows the absence or presence of autocorrelation.

The value of Durbin-Watson test indicates no autocorrelation among the variables as discussed already in the Table 3 and the resulted F-statistic shows both models are statistically significant at 95\% level of significance.

\subsubsection{Hausman Test}

The generally accepted way of choosing between fixed and random effects is running a Hausman test. Thus, in order to choose between fixed or random effect models, we run a Hausman test (Table 4). The null hypothesis for the Hausman test is that the preferred model is random effect and the alternative is the fixed effect (Green, 2008). It basically tests whether the unique errors are correlated with the regressors. To run a Hausman test one need to first estimate the fixed effects model, save the coefficients so that it can compared with the results of the next model, estimate the random effects model, and then do the comparison. Hausman test for both models are given below:

\begin{tabular}{l|ccc}
\hline \multicolumn{4}{c}{ Table 04: Hausman Test Result } \\
\hline \multicolumn{1}{c}{ Test Summary } & Chi-Sq. Stat. & Chi-Sq. d.f. & Prob. \\
\hline Model A & 50.85 & 5 & 0.0000 \\
Model B & 70.67 & 5 & 0.0000 \\
\hline
\end{tabular}

As the p-value of Hausman test for both the models is less than level of significance value, that is, $\mathrm{p}$-value less than 0.05 , therefore fixed effect model used. 


\subsubsection{Model "A" Results}

The results of model $\mathrm{A}$ is stated in Table 5. The table shows that the debt to equity ratio (gearing ratio) has a negative relationship with the profitability of Islamic banks and the coefficient is statistically significant at the $95 \%$ level of confidence. The size of the bank and operational efficiency both have a positive (Ali, Akhtar \& Ahmed, 2011) with the ROA. The asset management ratio also depicted a positive (Chirwa, 2003) significant relation with the ROA of Islamic banks and statistically the coefficients are significantly affected by the ROA. Similarly, a positive relationship is found between the capital adequacy ratio (Ali, Akhtar \& Ahmed, 2011) with coefficient being statistically significant at $5 \%$ level of significance. The $\mathrm{R}$ square value explained 81 percent variation in the ROA is explained by the independent variables.

\begin{tabular}{|c|c|c|c|c|}
\hline \multicolumn{5}{|c|}{ Table 05: Panel Least Square (Model - A) } \\
\hline \multicolumn{5}{|c|}{ Dependent Variable: ROA } \\
\hline Variable & Coefficient & Std. Error & t-stat & Prob. \\
\hline $\mathrm{C}$ & -3.490419 & 1.624791 & -2.148226 & 0.0396 \\
\hline $\mathrm{AM}$ & 15.63784 & 4.477847 & 3.492268 & 0.0015 \\
\hline BS & 0.418866 & 0.196291 & 2.133908 & 0.0409 \\
\hline GR & -0.789405 & 0.793638 & 1.998732 & 0.0512 \\
\hline CA & 0.488536 & 0.548039 & 0.891426 & 0.3796 \\
\hline $\mathrm{OE}$ & 19.92713 & 5.269388 & 3.781679 & 0.0007 \\
\hline$\overline{\mathrm{R}-\mathrm{sq}}$ & 0.810 & \multicolumn{2}{|c|}{ Prob(F-statistic) } & 0.000 \\
\hline F-statistic & 16.52 & \multicolumn{2}{|c|}{ Durbin-Watson stat } & 1.638 \\
\hline
\end{tabular}

\subsubsection{Model "B" Results}

The PLS regression results of model B is stated in Table 6.

\begin{tabular}{ccccc}
\hline \multicolumn{5}{c}{ Table 06: Panel Least Square (Model - B) } \\
\hline \begin{tabular}{ccccc} 
Dependent Variable: ROE \\
Variable & Coefficient & Std. Error & t-stat & Prob. \\
\hline C & -36.09164 & 18.10802 & -1.993130 & 0.0551 \\
AM & 124.5338 & 49.90483 & 2.495426 & 0.0181 \\
BS & 4.635240 & 2.187627 & 2.118844 & 0.0422 \\
GR & 6.742218 & 3.957330 & 2.089346 & 0.0376 \\
CA & 9.682882 & 6.107797 & 1.585331 & 0.1230 \\
OE & 127.0139 & 58.72643 & 2.162807 & 0.0384 \\
\hline R-squared & 0.843494 & Prob(F-statistic) & 0.000000 \\
F-statistic & 20.88436 & Durbin-Watson stat & 1.506669 \\
\hline
\end{tabular}
\end{tabular}


The resulted value of R-square in Model B explained that 84.34 percent variation in the ROE is explained by the independent variables approximately at the 0.05 level of confidence. The table findings suggest that the gearing ratio (Bashir, 2003; Amor et al., 2006), operational efficiency, bank size and asset management composition (Ali, Akhtar and Ahmed, 2011) have a positive and significant relationship with the Return on Equity at the 5\% level of significance, where as capital adequacy found statistically insignificant.

\section{Conclusion}

The study found that different measures of profitability depend upon different bank specific factors. The study found that ROA, as a measure of profitability of Islamic banks, depends on the leverage ratio, operating efficiency, capital adequacy ratio and CPI. Similarly, ROE found to be significant with the leverage (gearing) ratio, size of banks, operational efficiency and asset management ratio, but have no statistical relation with capital adequacy ratio. The study suggests that while measuring the profitability of Islamic banks, different parameters considers different bank specific characteristics Further research can be extended to explore the above findings and to include some other internal factors such as general bank charges, doubtful loans or reserves ratios, and external factor as well such as inflation, exchange rate, etc. 


\section{References}

Abreu, M., \& Mendes, V. (2002, May). Commercial bank interest margins and profitability: evidence for some EU countries. In Pan-European Conference Jointly Organised by the IEFS-UK \& University of Macedonia Economic \& Social Sciences, Thessaloniki, Greece, May (pp. 17-20).

Al-Tamimi, H. A. H. (2005). Factors influencing individual investor behavior: an empirical study of the UAE financial markets. The Business Review, 5(2), 225-233.

Athanasoglou, P. P., Brissimis, S. N., \& Delis, M. D. (2008). Bank-specific, industry-specific and macroeconomic determinants of bank profitability. Journal of international financial Markets, Institutions and Money, 18(2), 121136.

Ali, K., Akhtar, M. F., \& Ahmed, H. Z. (2011). Bank-Specific and Macroeconomic Indicators of Profitability-Empirical Evidence from the Commercial Banks of Pakistan. International Journal of Business and Social Science, 2(6), 235-242.

Almazari, A. A. (2014). Impact of Internal Factors on Bank Profitability: Comparative Study between Saudi Arabia and Jordan. Journal of Applied Finance \& Banking, 4(1), 125-140.

Bashir, A.M. (2003), "Determinants of the profitability in Islamic banks: some evidence from the Middle East", Islamic Economic Studies, Vol. 11, No. 1.

Bourke, P. (1989). Concentration and other determinants of bank profitability in Europe, North America and Australia. Journal of Banking \& Finance, 13(1), 65-79.

Chirwa, E.W. (2003), "Determinants of commercial banks' profitability in Malawi: A cointegration approach", Applied Financial Economics, Vol. ( 13),p. 565-77

Dr.Rajesh Kumar Singh \& Shkshi Chaudary 2009, Profitability Determinants of Banks in India, International Journal of Global Business, No. 2, pp.163-180

Deger Alper \& Adem Anbar 2011, Bank Specific and Macroeconomic Determinants of Commercial Bank Profitability: Empirical Evidence from Turkey, Business and Economics Research Journal, No. 2,pp. 139-152

Flamini, V., Schumacher, L., \& McDonald, C. A. (2009). The determinants of commercial bank profitability in Sub-Saharan Africa. International Monetary Fund.

Hassan, M. K., \& Bashir, A. H. M. (2003, December). Determinants of Islamic banking profitability. In 10th ERF Annual Conference, Morocco (pp. 16-18).

Ijaz, F. Impact of Income Components in Determine the Market ValueEvidence from Pakistan Cement Industry. Cell, 92, 332-4838919. 
Islamic Banking Bulletin June 2013 Islamic Banking Department State Bank of Pakistan. (2013), (June).

Jham, V., \& Khan, K. M. (2008). Determinants of performance in retail banking: Perspectives of customer satisfaction and relationship marketing. Singapore Management Review, 30(2), 35-45.

Goddard, J., Molyneux, P., \& Wilson, J. O. (2004). The profitability of european banks: a cross-sectional and dynamic panel analysis. The Manchester School, 72(3), 363-381.

Khan, M. M. S., \& Ijaz, F. (2014). Islamic Banking in Pakistan: Challenges and Opportunities-A Performance Based Analysis. Islamic Banking and Finance Review, 47.

Kim, Mihwa and Kim, II-woon(1997), "The Structure- Profit Relationship of Commercial Banks in South Korea and the United States: A comparative Study", Multinational Business Review, Vol. 5(2), p. 81-94.

Lloyd-Williams, D.M., Phillip Molyneux, and John Thronton, (1994). " Market Structure and Performance in Spanish Banking," Journal of Banking and Finance, 18, 433-443

Molyneux, P., \& Thornton, J. (1992). Determinants of European bank profitability: A note. Journal of banking \& Finance, 16(6), 1173-1178.

Naceur,S.B. and Goaied M.(2001), "The determinants of the Tunisisian deposit banks' performance", Journal of Applied Financial Economoics, Vol, 11, p.317-319. ORISIS database, University of Sharjah Library.

Ostadi, H., \& Monsef, N. (2014). Assessing the Impact of Bank Concentration and Liquidity of Refah Bank Branches on Profitability during the Period1383-190. International Journal of Human Resource Studies, 4(1), Pages-248.

Pang, J., (1995), Banking and Finance in Malaysia'. Federal Publications Sdn. Bhd. Malaysia.

Riaz, S. (2013, January). Profitability Determinants of Commercial banks in Pakistan. In Proceedings of 6th international Business and Social Sciences research Conference. Dubai, UAE.

Short, B. K. (1979). The relation between commercial bank profit rates and banking concentration in Canada, Western Europe, and Japan. Journal of Banking \& Finance, 3(3), 209-219.

Siddiqui, A. (2008). Financial contracts, risk and performance of Islamic banking. Managerial Finance, 34(10), 680-694.

Wum, Hsiu-Ling, Chen, Chien-Hsun, Shiu, Fang-Ying ( 2007), "The impact of financial development and bank characteristics on the operational performance of commercial banks in the Chinese transitional economy", Journal of Economic Studies, Vol. 34(5), p. 401-414. 


\section{Websites}

- www.burjbankltd.com/

- www.dibpak.com/

- www.albaraka.com.pk/

- www.meezanbank.com/

- www.bankislami.com.pk/ 


\section{Appendix}

\section{Islamic Banks in Pakistan}

Meezan Bank Limited: Meezan Bank Limited is a publicly listed company incorporated on January 27, 1997 and started operations as an investment bank in August, 1997. Meezan bank has the honor of being the country's first full-fledged Islamic commercial banking license by the SBP. The main shareholders of banks are Noor Financial Investment Company, Pak-Kuwait Investment Company and the Islamic Development Bank of Jeddah.

Burj Bank Limited: Burj Bank Limited, previously Dawood Islamic bank Limited, a unique Islamic bank which offers the service level of an international bank while presenting a diverse portfolio of Islamic products. This bank got license in 2006 and starts operation in 2007. Burj Bank has a rich Middle Eastern background with financial and technical support.

Bank Islami Pakistan Limited: The SBP issued a No Objection Certificate (NOC) in no time on August 19, 2004 and Bank Islami Pakistan Limited, the second full-fledge Islamic Commercial Bank in Pakistan, was incorporated on October 18, 2004 in Pakistan. The bank is the first to receive the Islamic banking license under the Islamic Banking policy of 2003 on March 31, 2005..

Dubai Islamic Bank Pakistan Limited: Dubai Islamic Bank Pakistan Limited (DIBPL) commenced operations in 2006. Since then, DIBPL has undertaken major initiatives to expand its branch network across the country. Dubai Islamic bank launched Pakistan's first Islamic Visa Debit Card and introduced financial products covering Home Financing, Auto Financing, and Depository products.

Al Baraka Bank (Pakistan) Limited: Al Baraka Bank (Pakistan) Limited has the honor of being the pioneer of Islamic banking in Pakistan. The bank is merger of Al Baraka Islamic Bank Bahrain and Emirates Global Islamic Bank Pakistan. Over the years, the bank has successfully developed and maintained its identity as one of the leading providers of a host of banking products and services in strict compliance with Shariah principles. 